NOTES ON NIGHTINGALE 
A volume in the series

The Culture and Politics of Health Care Work

edited by Suzanne Gordon and Sioban Nelson

A list of titles in this series is available at www.cornellpress.cornell.edu. 


\section{NOTES ON NIGHTINGALE}

\section{THE INFLUENCE AND LEGACY OF A NURSING ICON}

EDITED BY

SIOBAN NELSON AND ANNE MARIE RAFFERTY

\section{ILR PRESS}

AN IMPRINT OF

CORNELL UNIVERSITY PRESS

ITHACA AND LONDON 


\section{Copyright (C) 2010 by Cornell University}

All rights reserved. Except for brief quotations in a review, this book, or parts thereof, must not be reproduced in any form without permission in writing from the publisher. For information, address Cornell University Press, Sage House, 512 East State Street, Ithaca, New York 14850.

First published 2010 by Cornell University Press

First printing, Cornell Paperbacks, 2010

Printed in the United States of America

\section{Library of Congress Cataloging-in-Publication Data}

Notes on Nightingale : the influence and legacy of a nursing icon / edited by Sioban Nelson and Anne Marie Rafferty.

p. cm. - (The culture and politics of health care work)

Includes bibliographical references and index.

ISBN 978-0-8014-4906-2 (cloth : alk. paper) -

ISBN 978-0-8014-7611-2 (pbk. : alk. paper)

1. Nightingale, Florence, 1820-1910-Influence. 2. NursingPhilosophy. I. Nelson, Sioban. II. Rafferty, Anne Marie.

III. Series: Culture and politics of health care work.

RT37.N5.N68 2010

610.73-dc22

Cornell University Press strives to use environmentally responsible suppliers and materials to the fullest extent possible in the publishing of its books. Such materials include vegetable-based, low-VOC inks and acid-free papers that are recycled, totally chlorine-free, or partly composed of nonwood fibers. For further information, visit our website at www.cornellpress.cornell.edu.

Cloth printing $\begin{array}{llllllllll}10 & 9 & 8 & 7 & 6 & 5 & 4 & 3 & 2 & 1\end{array}$

Paperback printing $\quad 10 \begin{array}{llllllllll}10 & 9 & 8 & 7 & 6 & 5 & 4 & 3 & 2 & 1\end{array}$ 